\title{
Estimation of above-ground biomass in forest stands from regression on their basal area and height
}

\author{
Mait Lang ${ }^{1,2^{*}}$, Ando Lilleleht ${ }^{2}$, Mathias Neumann ${ }^{3}$, Karol \\ Bronisz $^{4}$, Samir G. Rolim ${ }^{5}$, Meelis Seedre ${ }^{6}$, Veiko Uri $^{2}$ and \\ Andres Kiviste ${ }^{2}$
}

Lang, M., Lilleleht, A., Neumann, M., Bronisz, K., Rolim, S.G., Seedre, M., Uri, V., Kiviste, A. 2016. Estimation of above-ground biomass in forest stands from regression on their basal area and height. - Forestry Studies | Metsanduslikud Uurimused 64, 70-92. ISSN 1406-9954. Journal homepage: http:// mi.emu.ee/forestry.studies

\begin{abstract}
A generic regression model for above-ground biomass of forest stands was constructed based on published data $\left(R^{2}=0.88, R S E=32.8 \mathrm{t} / \mathrm{ha}\right)$. The model was used 1) to verify two allometric regression models of trees from Scandinavia applied to repeated measurements of 275 sample plots from database of Estonian Network of Forest Research (FGN) in Estonia, 2) to analyse impact of between-tree competition on biomass, and 3) compare biomass estimates made with different European biomass models applied on standardized forest structures. The model was verified with biomass measurements from hemiboreal and tropical forests. The analysis of two Scandinavian models showed that older allometric regression models may give biased estimates due to changed growth conditions. More biomass can be stored in forest stands where competition between trees is stronger. The tree biomass calculation methods used in different countries have also substantial influence on the estimates at stand-level. A common database of forest biomass measurements from Europe in similar to pan-tropical tree measurement data may be helpful to harmonise carbon accounting methods.
\end{abstract}

Key words: forest, biomass, model, competition.

Authors' addresses: ${ }^{1}$ Tartu Observatory, 61602 Tõravere, Tartumaa, Estonia; ${ }^{2}$ Institute of Forestry and Rural Engineering, Estonian University of Life Sciences, Kreutzwaldi 5, 51014 Tartu, Estonia; ${ }^{3}$ Institute of Silviculture, Department of Forest and Soil Sciences, University of Natural Resources and Life Sciences, Vienna, Peter-JordanStr. 82, A-1190 Wien, Austria; ${ }^{4}$ Department of Dendrometry and Forest Productivity, Faculty of Forestry, Warsaw University of Life Sciences, Nowoursynowska 159, 02787 Warsaw, Poland; ${ }^{5}$ Restinga and Atlantic Forest Laboratory, Universidade Federal do Espírito Santo, UFES, 29932-540, São Mateus, ES, Brazil; ${ }^{6}$ Faculty of Forestry and Wood Sciences, Czech University of Life Sciences, Kamycka 129, 16521 Prague, Czech Republic; *e-mail: mait.lang@to.ee

\section{Introduction}

Forests are an integral part of the global carbon (C) cycle and a large $C$ reservoir that is mitigating climate change (Nabuurs et al., 2007). Accurate estimation of the rate of biomass and $\mathrm{C}$ accumulation and stor-

DOI: 10.1515/fsmu-2016-0005

(C) 2016 Estonian University of Life Sciences. All rights reserved age in forest stands is central for understanding how forests have, and will influence climate. However, Neumann et al. (2016) found large discrepancies between tree biomass estimates when methods used in different European countries were compared. Typically, forest biomass compo- 
nents (stem wood, stem bark, foliage, living branches, stump or root system) are estimated with single tree regression models (Ter-Mikaelian \& Korzukhin, 1997; Zianis et al., 2005; Henry et al., 2013) based on tree stem diameter at breast height $(d)$. Only a few of the models are based on extensive sample of trees across different growth conditions (Marklund, 1988; Repola, 2008, 2009; Chave et al., 2005, 2015). However, systematic errors may occur when $d$-based allometric regression models are applied in stands of different structure (stand density, competition etc.) compared to the model data. The structure of forest stands depends on species composition, soil fertility, stand density, management, competition between trees and disturbances (Bormann \& Likens, 1992; Schietti et al., 2016).

When a tree is used as an independent sample then the rate of biomass accumulation increases with the tree size as estimated by Stephenson et al. (2014) based on allometric regression models which have $d$ as an independent variable. On the other hand, the fact that bigger trees require each more space compared to small trees for sustaining their growth is well known from allometric theory (Enquist \& Niklas, 2002; Nilson, 2005) and also from yield tables used for forest management practice for more than a century (Vanclay, 1994). Forest canopy level feedback loops (Hasenauer, 1997; Frey, 2009) result in a relatively stable crown cover, leaf area index and amount of absorbed photosynthetically active radiation (Nilson \& Peterson, 1994) in the absence of stand structure altering disturbances (Schietti et al., 2016). Hence, tree growth is determined by the potential phytoproductivity of soil (Kõlli, 2002; Kõlli \& Kanal, 2010) and biomass accumulation rate per unit area of a forest is influenced by the tree growth induced competition (Contreras et al., 2011) and limited by tree mortality. An important factor in biomass accumulation, the stem wood density, is influenced by the forest stand basal area increment (Jaakkola et al., 2005) which de- pends on soil fertility (Kask \& Pikk, 2009) and species composition (Lilleleht, 2011). Marklund (1988) found that inclusion of basal area increment improved the accuracy of allometric tree biomass models.

Cannell (1984) showed that a simple model $\ln \left(B_{A G}\right)=-0.37+0.84 \ln (G H)$ described $91 \%$ of the above-ground biomass $B_{A G}(\mathrm{t} / \mathrm{ha})$ variation for a dataset of 640 forest stands based on the product of the stand mean height $H(\mathrm{~m})$ and basal area per unit area $G\left(\mathrm{~m}^{2} / \mathrm{ha}\right)$. In forestry, $G H$ is used to calculate standing wood volume $V=G H F$, where $F$ is stem form factor of the stand (Krigul, 1972). In biomass studies $F_{s+b}$ is calculated accounting for stems and branches (Nebel et al., 2001). F can be based on parabolic height (Cannell, 1984) or cylinder (Krigul, 1972). Cannell (1984) presented also tree species-specific linear biomass models. However, new measurements of $B_{A G}$ have been published since offering an opportunity to further explore and develop this model. If the model is still valid, it could be used as a standard tool in those geographic areas where forest biomass models are not available. The stand height and basal area-based biomass models are also useful for remote sensing applications (Wulder et al., 2008; Asner et al., 2012; Hayashi et al., 2015; Arumäe \& Lang, 2016; Moreno et al., 2016).

Our primary aim was to 1 ) develop a generic, species independent, above-ground biomass model for forest stands based on stand height and basal area, 2) verify tree biomass models regarding competition, and 3) compare the generic model-based estimates with biomass measurement data and published estimates of biomass. Firstly, we collected published data of standlevel above-ground biomass and stand structure (trees per unit area $(N)$, mean tree stem breast height diameter $D$, forest height $H$ and $G$ ) and estimated parameters for generic biomass model. Secondly, tree biomass regression models were applied to trees growing on Estonian Network of Forest Research (Kiviste et al., 2014) sample 
plots and the aggregated estimates were compared to the generic model and analysed in respect to two simple stand structure indices. Additional data sets used in the validation and analysis of the generic model were artificial stands (Neumann et al., 2016), published oak biomass data from Korea, rainforest data from Amazon and Chile, and sample plot measurement data from Poland, Estonia and Brazil.

\section{Material and Methods}

\section{Model construction}

When the biomass data (Table A1.1) was plotted as a function of $G H$ the relationship was linear with only few outliers. It can be expected that wood density $(\delta)$, stand form factor $F$ and biomass allocation into stem, crown and root system will cause some deviations from the general trend. It is possible that stand structure variables e.g. form factor or mean height are not exactly defined and the given values in publications are not compatible. The outliers were two temperate mixed deciduous forests (Newman et al., 2006) showing small biomass for GH and Quercus stands in Korea (Son et al., 2004) with big biomass at GH compared to Park et al. (2005).

After excluding the outliers which substantially deviated from the dataset, the relationship between forest above-ground biomass was first estimated with linear model

$B_{A G}=a_{1}+a_{2} G H$

(Figure 1, Table 1). The linear model did not work well in young stands and predicted $25.4 \mathrm{t} / \mathrm{ha}$ biomass for the stands with $G H=0$. The second, advanced version of the model with start correction component

$B_{A G}=a_{1}+a_{2} G H+a_{3} \exp (-G H / 100)$

estimates reasonably $7 \mathrm{t} / \mathrm{ha}$ at $\mathrm{GH}=0$. For example, above-ground biomass estimate of a young Norway spruce stand with $H=$ $100 \mathrm{~cm}$ and $N=2000$ trees $/$ ha is $2.4 \mathrm{t} / \mathrm{ha}$ according to the model from Pastorella \& Paletto (2014) and $0.5 \mathrm{t} / \mathrm{ha}$ according to Mitt et al. (2014).

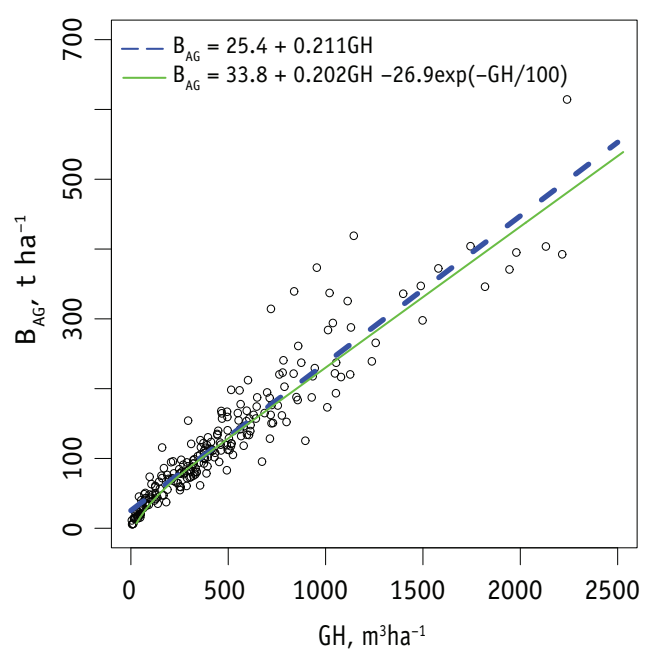

Figure 1. Predictions of model (1) and (2) and the observed values (points) of stand aboveground biomass.

Joonis 1. Puistute maapealse osa biomassi $\mathrm{B}_{\mathrm{AG}}$ seost rinnaspindala (G) ja kõrguse (H) korrutisega kirjeldavad mudelid (1) ja (2). Algandmed on tabelis A1.1.

Table 1. The parameter estimates for model (1) and (2). All model parameters (standard error in parentheses) were significant at $p<0.05$. RSE is model standard error.

Tabel 1. Puistute maapealse osa biomassi mudelid. Sulgudes on standardviga.

\begin{tabular}{lcc}
\hline Model component / & \multicolumn{2}{c}{ Model / Mudel } \\
\cline { 2 - 3 } Mudeli osa & $(1)$ & $(2)$ \\
\hline$R_{\text {adj }}^{2}$ & 0.8816 & 0.8844 \\
Deg. of freedom & 225 & 224 \\
$R S E$ (t/ha) & 33.2 & 32.8 \\
$a_{1}$ & 25.36 & 33.83 \\
& $(3.3)$ & $(4.7)$ \\
$a_{2}$ & 0.2110 & 0.2020 \\
& $(0.0051)$ & $(0.062)$ \\
$a_{3}$ & - & -26.86 \\
& & $(10.6)$ \\
\hline
\end{tabular}


To estimate the impact of individual publications and individual stands on the model (2) the biomass data from literature was randomly sampled into 1000 calibration and validation subsets. In Table (2) are the percentiles ( $\mathrm{t} / \mathrm{ha}$ ) of the $\mathrm{GH}$-based biomass model (2) residual standard error (RSE), root mean squared error (RMSE) and mean estimation error (MEE). MEE and RMSE are based on validation subsets.

Table 2. Dependence of model (2) on sample data. Subsets "rs" are random selection of stands, "rp" are random selection of publications.

Tabel 2. Võimalik algandmete mõju mudelile (2) kui algandmestik jagati 1000 katses mudeli andmeteks ja valideerimise andmeteks. Valiti puistuid "rs" ja teises katses publikatsioone "rp".

\begin{tabular}{|c|c|c|c|c|c|c|}
\hline \multirow{2}{*}{$\begin{array}{l}\text { Estimator / } \\
\text { Veahinnang }\end{array}$} & \multirow{2}{*}{$\begin{array}{c}\text { Subset / } \\
\text { Valim }\end{array}$} & \multicolumn{5}{|c|}{ Percentiles / Protsentiilid } \\
\hline & & $0 \%$ & $25 \%$ & $50 \%$ & $75 \%$ & $100 \%$ \\
\hline RSE & rs & 23 & 30 & 33 & 35 & 40 \\
\hline RMSE & rs & 22 & 31 & 34 & 36 & 46 \\
\hline MEE & rs & -15 & -3 & 0 & 3 & 14 \\
\hline RSE & rp & 13 & 23 & 29 & 38 & 50 \\
\hline RMSE & rp & 15 & 26 & 35 & 40 & 55 \\
\hline MEE & rp & -24 & -8 & -1 & 7 & 23 \\
\hline
\end{tabular}

\section{Model analysis on forest growth study network data}

A subset of 275 sample plots (FGN stands) was extracted from the database of Estonian Network of Forest Research (Kiviste et al., 2014). Considering all repeated measurements on the sample plots the total number of observations was 1037. Main tree species in the forests were Scots pine, Norway spruce, silver birch and trembling aspen. All the forests were older than 20 years when first measured (Table A1.2). Tree height for the trees without height measurement was estimated from model of Näslund fitted on the sample trees for each sample plot. The intercept of the model was fixed and two parameters were estimated according to
Padari (1999). Three above-ground biomass $b_{A G}$ estimates for each tree were calculated based on $d$ and $h: 1) b_{A G(R)}$ as sum of fractions (foliage, branches, stem, bark, stump) by using by using simple multivariate models from Repola $(2008,2009), 2) b_{A G(M)}$ by using corresponding models from Marklund (1988), and 3) $b_{A G(C h)}=0.0673\left(d^{2} h \delta\right)^{0.976}$ with the model (4) from Chave et al. (2015) by using wood density given in Table A3.1. Total above-ground biomass $B_{A G}, G$ and basal area weighted $H$ (Lorey height) were calculated for each sample plot. By using $G$ and $H$ biomass estimate with Cannell (1984) model $\ln \left(B_{A G}\right)=-0.37+0.84 \ln (G H)$ was calculated for each FGN sample plot.

We used two stand structure indices to analyse the single tree-based biomass estimates of FGN stands in respect to the model (2). Hegyi (1974) index of competition for a sample plot

$C I_{\text {Hegyi }}=1 / N_{t} \sum_{j=1}^{N_{t}} \sum_{i=1}^{n} d_{i} /\left(d_{j} S_{i j}\right)$

is based on distance $s_{i j}$ from target tree $j$ to the $i$-th neighbour tree considering competition radius of $8 \mathrm{~m}$. Only the trees from upper layer were included for $C_{\text {Hegyi }}$. We did not apply sample plot extension as described by Lilleleht et al. (2014) in this test; instead, the list of target trees $N_{t}$ was limited to those located by $8 \mathrm{~m}$ towards the centre from sample plot border. Increase in $C_{\text {Hegyi }}$ indicates increase in competition. The second index

$C I_{L T J}=L / L_{T J}$

is based on mean distance between trees $L=(100 / \sqrt{N})$ and Nilson's model of forest stand self-thinning $L_{T J}=k_{1}+k_{2} D+k_{3} D H_{100}$ $+k_{4} H_{100}$ for different species (Sims et al. 2009), where $H_{100}$ is site fertility index. The value of $C I_{L T J}=1$ means that the stand is on the self-thinning line and $C I_{L T J}<1$ indicates intensive self-thinning due to insufficient growth space.

To describe the variation in stand-level biomass explained by the competition indi- 
ces we constructed general additive models (GAM) with simple isotropic smooth in $\mathrm{R}$ computing environment using library "mgcv". The dependent variables were stand biomass estimates based on $b_{A G(R)}$ and $b_{A G(M)}$ and their normalized values in respect to the model (2).

\section{Model assessment on simulated stand structures}

The second dataset (FORMIT stands) contained simulated standardized forest structures for Scots pine, Norway spruce, silver birch, European beech, and common oak. The dataset was adopted from Neumann et al. (2016) who compared forest carbon estimation methods across the Europe. The data set was generated with STANDGEN (Kittenberger, 2003), that includes single tree simulation model MOSES (Hasenauer, 1994; Klopf et al., 2011). With STANDGEN, for each of the five selected tree species, three of 0.25 hectare stands were generated which differed in mean and standard deviation of tree diameter and represented forest stands at different ages, allocation, stem number, or stocking density. The generated stands corresponded to a young stand (quadratic mean $D=10 \mathrm{~cm}$ with standard deviation $1 \mathrm{~cm}$ ), a middle-aged stand $(30 \mathrm{~cm} \pm 5 \mathrm{~cm})$, and an old stand $(50 \mathrm{~cm} \pm 10 \mathrm{~cm})$. The country-specific above-ground biomass estimates of FORMIT stands were compared to model (2).

\section{Biomass data and published biomass estimates for model assessment}

Silver birch biomass data were from 18 stands growing on abandoned agricultural land in the Mazowsze region (central Poland). Scots pine data contain empirical biomass material from 18 managed stands in Bory Lubuskie (western Poland) from different site conditions and age. In each stand the sample plots consisted of approximately 200 trees. More details are given by Zasada et al. (2014) and Bronisz \& Zasada (2016).

Biomass data from 23 grey alder stands (Uri et al., 2014) from Estonia were used. The stands were not used for parameter estima- tion for model (2). Foliage mass for the grey alder stands was not measured. For 7-years and older stands constant foliage mass estimate of $3 \mathrm{t} /$ ha was used (Aosaar et al., 2013). Foliage mass for younger stands was scaled linearly starting from $0.5 \mathrm{t} /$ ha for 2-years old grey alder stand. Woody aboveground biomass was calculated from stem and branch volume using biomass density. Also species-specific models for silver birch and grey alder were estimated by using the formulation of model (2).

We also analysed data from three $(100 \times$ $100 \mathrm{~m})$ permanent plots within an oldgrowth Atlantic moist forest in Vale Natural Reserve, south eastern of Brazil, where all stems with $d \geq 10 \mathrm{~cm}$ were measured at $1.3 \mathrm{~m}$ height or above any buttresses (for site description see Rolim et al. 2016). For estimates of aboveground biomass except Arecaceae species we applied a pantropical allometric model developed by Chave et al. ((4): 2015), and species-specific wood density from global database published by Chave et al. (2009). For Arecaceae species the model from Goodman et al. (2013) was used.

Additional published data were from oak forest in Korea (Li et al., 2012) (includes Son et al., 2004; Park et al., 2005) and stand level biomass data by age classes for oak forests in Poland (Orzeł et al., 2006). Rice et al. (2004) provided sufficient data in their Table 5 for an old-growth Amazon rainforest to calculate $G$ and they also gave an estimate of the closed canopy height $(40 \mathrm{~m})$ and the emergent tree height $(55 \mathrm{~m})$. We used an estimate of $H=45 \mathrm{~m}$ for our calculations. Nebel et al. (2001) used $F_{s+b}=0.6$ to calculate stem and branch volume for high restinga, low restinga and tahuampa forest in Peruvian Amazon. We calculated initial $G H=V / 0.6$ for the stands. We found also biomass data for Fitzroya cupressoides forest (Urrutia-Jalabert et al., 2015) and included in comparison the data for trees with $d \geq 10 \mathrm{~cm}$. Form factor conversion for tropical forest to adopt the data for $\mathrm{GH}$-based model is given in Appendix A2. 


\section{Results}

\section{Stand-level biomass estimates in FGN forests}

The estimated biomass in FGN sample plots was better described by stand height than stand mean diameter for Estonian forests (Figure A4.1). The mean above-ground biomass of FGN forests $B_{A G(R)}=166.5 \mathrm{t} / \mathrm{ha}$ was estimated with Repola (2008, 2009) model, $B_{A G(M)}=184.1 \mathrm{t} /$ ha with Marklund (1988) model and $B_{A G(C h)}=204.9 \mathrm{t} /$ ha with the model from Chave et al. (2015). In the FGN forests, $B_{A G(R)}$ was in average $3.2 \mathrm{t} /$ ha less compared to Cannell (1984) model and $10.7 \mathrm{t} /$ ha less compared $B_{A G(2)}$ estimated with model (2) and $B_{A G(M)}$ was respectively $14.4 \mathrm{t}$ / ha and $6.9 \mathrm{t}$ / ha more (Figure 2).

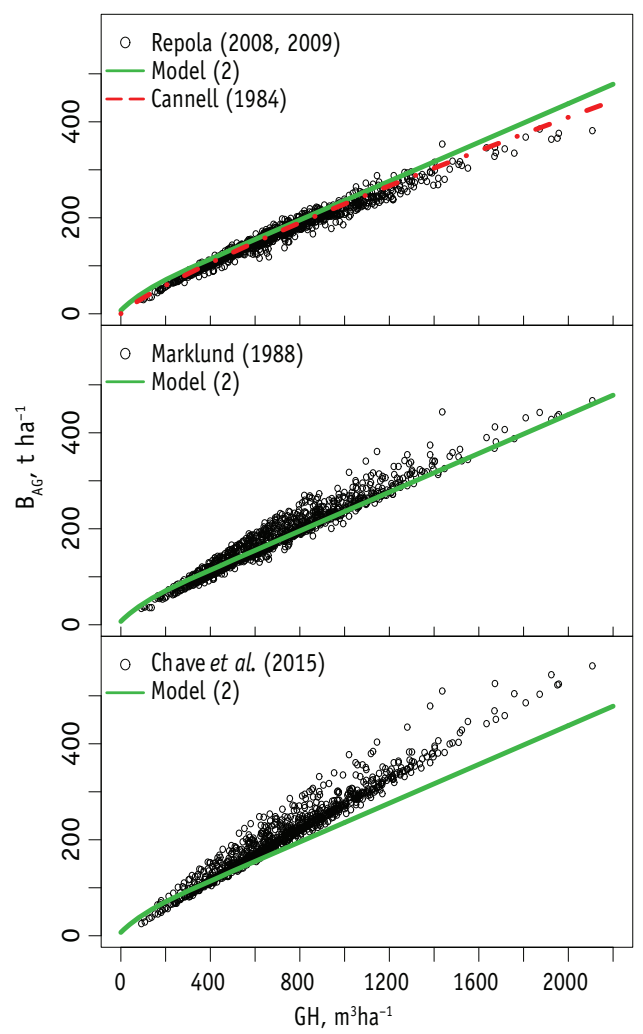

Figure 2. Above-ground biomass of FGN forests as a function of stand basal area and height.

Joonis 2. Puistu maapealse osa biomass metsa kasvukäiguproovitükkidel hinnatuna erinevate mudelitega.

\section{Biomass as a function of competition indices}

The correlation of above-ground biomass estimates was negative with CI-s. However, the numeric values of $C I_{H e g y i}$ and $C I_{L T J}$ have opposite meanings i.e. stronger competition is indicated by bigger values of $\mathrm{CI}_{\mathrm{Hegyi}}$ and smaller values of $C I_{L T J}$, and the conclusions depend on particular $\mathrm{CI}$. Based on $\mathrm{CI}_{\mathrm{Heg} y i}$ less biomass is stored in the stands where competition is stronger. This is influenced by the characteristics of $C_{\text {Hegyi }}$ which becomes a function of $L$ when averaged over all trees in a sample plot. Stronger competition according to $\mathrm{CI}_{\mathrm{Hegyi}}$ exists in denser stands which are also younger in Estonia. According to $C_{L T J}$ more biomass is stored in stands where intensive self-thinning process indicates stronger competition.

The CI-s explained up to $76 \%$ of variation in biomass (Table 3) when no other predictive variables were included in GAMmodel. $C I_{L T J}$ described 34 to $76 \%$ of variation in biomass estimates except for $B_{A G(R)}-B_{A G(2)}$ in pine stands. Self-thinning process was intensive in many of the stands according to $C_{L T J}$, but the $B_{A G(R)}$ was substantially less than $B_{A G(2)}$ (Figure 3) and the relationship was scattered. The $C I_{L T J}$ had strong negative correlation with stand basal area (-0.7) and the correlation was negative (-0.6) with both $B_{A G(R)}$ and $B_{A G(M)}$. This was also reflected in the relationships of $C_{L T J}$ with $B_{A G(R)}-B_{A G(2)}$ and $B_{A G(M)}-B_{A G(2)}$ (Figure 3).

$C I_{\text {Hegyi }}$ described $21-66 \%$ of variation of the difference $B_{A G(R)}-B_{A G(2)}$ and much less for other analysed biomass variables (Table 3). When $C I_{\text {Hegyi }}$ had smaller values (less competition) then $B_{A G(R)}$ was also less compared to the generic model (2). The relationship was much more scattered for $B_{A G(M)}$ (Figure 3) with most of this scatter in $B_{A G(M)}-B_{A G(2)}$ attributed to deciduous stands and Norway spruce stands. The $C I_{\text {Hegyi }}$ had smaller values in older stands (correlation $\left.\left(A, C I_{\text {Hegyi }}\right)=-0.42\right)$ where stand density is less than in younger stands. Both CI-s did, however, improve only marginally $B_{A G}$ estimates when included as third variable 
Table 3. Percentage of variation in biomass described by competition indices using general additive models with isotropic smooth function.

Tabel 3. Biomassi variatsioon, mida konkurentsiindeksid (CI) kirjeldavad.

\begin{tabular}{lccccc}
\hline $\mathrm{Cl}$ & Main species & \multicolumn{4}{c}{ Described \% of biomass variation / Kirjeldatud variatsioon (\%) } \\
\cline { 3 - 6 } & Peapuuliik & $B_{A G(R)}-B_{A G(2)}$ & $B_{A G(M)}-B_{A G(2)}$ & $B_{A G(R)}$ & $B_{A G(M)}$ \\
\hline$C l_{\text {Hegyi }}$ & Spruce & 66.3 & 8.1 & 2.3 & 3.6 \\
$C_{\text {Hegyi }}$ & Pine & 59.3 & 17.8 & 24.6 & 27.4 \\
$C l_{\text {Hegyi }}$ & Deciduous & 21.2 & 2.4 & 5.1 & 3.6 \\
\hline$C l_{L T J}$ & Spruce & 34.4 & 76.4 & 65.0 & 61.7 \\
$C l_{L T J}$ & Pine & 3.8 & 45.1 & 55.1 & 52.3 \\
$C l_{L T J}$ & Deciduous & 46.9 & 59.7 & 61.5 & 61.0 \\
\hline
\end{tabular}

with $G$ and $H$ which described over $94 \%$ variation in $B_{A G}$.

The influence of competition to the relationship of biomass on $\mathrm{GH}$ occurs due to form factor decrease (correlation $\left(F, C_{\text {Hegyi }}\right)$ $=0.65) . F$ decreases with tree height and depends on height to stem diameter ratio. Weaker competition stipulates stem diameter growth more than tree height growth and causes smaller form factor of stems but the share of branches increases (Larson, 1963). In FGN forests $C I_{\text {Hegyi }}$ described $38 \%$ of variation in branch biomass to total above-ground biomass ratio $B_{\text {branch( } R)} /$ $B_{A G(R)}$ in broadleaved-species dominated forests with moderate negative correlation. Less than $11 \%$ of $B_{\text {branch(R) }} / B_{A G(R)}$ variation in pine and spruce dominated forests was described by $\mathrm{CI}_{\text {Hegyir }}$, but there was a weak positive correlation. $C I_{L T J}$ described less than $15 \%$ of the $B_{\text {branch(R) }} / B_{A G(R)}$. From Marklund (1988) we used models that estimated biomass sum of foliage and branches i.e $B_{\text {crown }(M) \text {. }}$. The variation of $B_{\text {crown(M) }} / B_{A G(M)}$ described by $C I_{\text {Hegyi }}$ was $32 \%$ in spruce stands, $26 \%$ in pine stands with moderate positive correlation. There was no correlation between $B_{\text {crown(M) }} /$ $B_{A G(M)}$ and $C I_{\text {Hegyi }}$ in deciduous stands. $C I_{L T J}$ had almost no correlation with $B_{\text {crown }(M)} /$ $B_{A G(M)}$ in pine stands, but there was moderate positive correlation in deciduous stands and spruce stands although less than $23 \%$ of variation in was described. For comparison,
$B_{\text {crown }(M)} / B_{A G(M)}$ had strong negative correlation with stand height and moderate negative correlation with basal area.

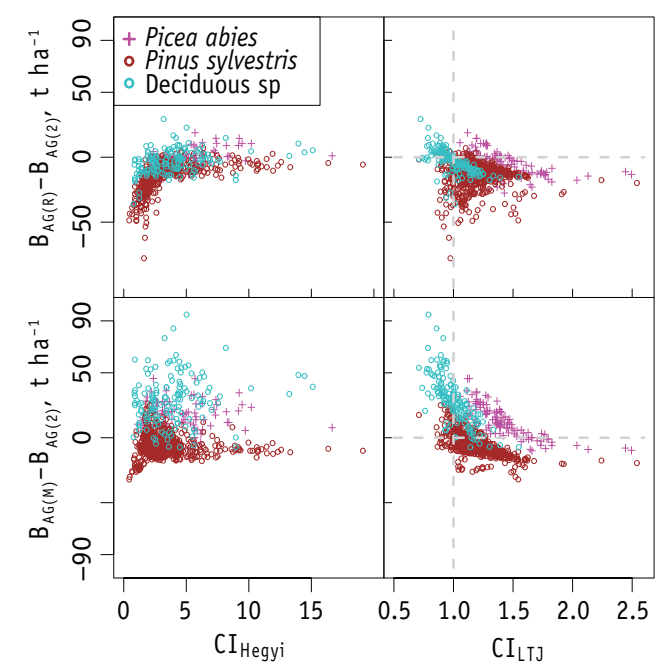

Figure 3. Difference of aggregated single tree biomass $B_{A G}$ in FGN forests from that predicted by model (2) as a function of Hegyi (3) and Nilson's (4) CI-s.

Joonis 3. Üksikpuude mudelitel põhineva puistu biomassi erinevus üldisest mudelist (2) sõltuvalt Hegyi (3) ja Nilsoni (4) konkurentsiindeksitest metsa kasvukäiguproovitükkidel. 


\section{Model assessment on simulated stand structures}

The biomass estimates for simulated stands with country-specific models had a rather large scatter (Figure 4). Biomass estimate for Norway spruce with Spanish model yielded exceptionally large biomass compared to model (2) and models from other countries. However, on average the biomass estimates for Norway spruce, Scots pine and silver birch were mostly in line with the model (2). The generic model (2) underestimates biomass in beech and oak stands because the species have denser wood (Figure 4). Sample plot data from literature (Cannell, 1982; Bartelink, 1997) show also high biomass density for beech forests. Biomass estimates with model of Orzeł et al. (2006) are smaller than predicted with national biomass models for FORMIT oak stands, but still greater than estimated with the GH-based model (2).

\section{Biomass measurement data and published data for model assessment}

The model (2) does not work well on Quercus mongolica and Quercus variabilis forest data from review by Li et al. (2012) (Figure 5). No data was available for form factor assessment. The structure of the forests was described by their arithmetic mean $D$ and arithmetic mean $H$, the number of trees per hectare and forest age. We estimated stem biomass density by assuming stem form factor $F=0.5$ (Lumbres et al., 2014) as $\delta=B_{A G, \text { stem }} /(0.5 G H)$ and the results ranged from 0.16 to $2.0 \mathrm{~g} / \mathrm{cm}^{3}$. By choosing other realistic stand or stem form factor values (Cannell, 1984; Jung et al., 2015) the stem organic matter density estimates did not substantially improve.

However, when sufficient data was available for stand form factor conversion, then it was possible to compare biomass estimates from tropical forests with hemiboreal forests by their GH (Figure 5). Compared to the model (2) an old-growth Amazon rainforest (Rice et al., 2004), old-growth Atlantic forest and flood plain forests in the Peruvian Amazon (Nebel et al., 2001)

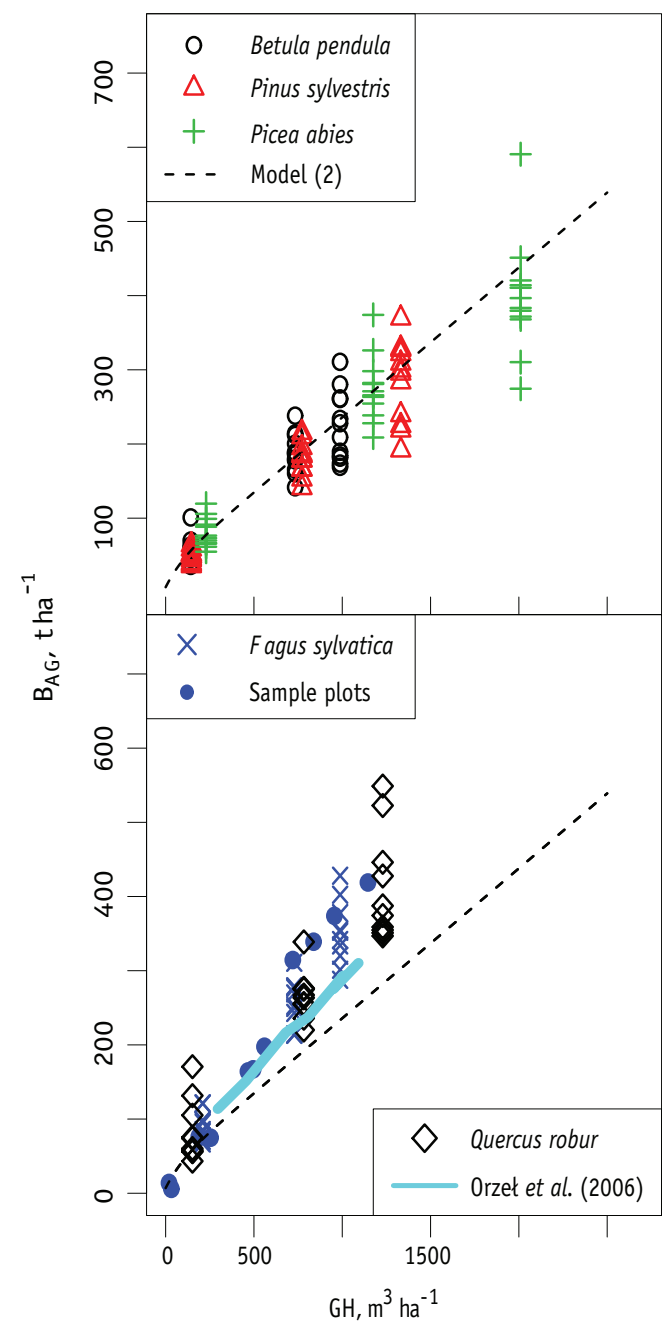

Figure 4. Biomass was predicted with country specific models for five species each forming three stands (Neumann et al., 2016) characterized by different $D$. Sample plots are beech forests from Bartelink (1997) and Cannell (1982).

Joonis 4. Erinevate maade biomassimudelitega (Neumann et al., 2016) saadud hinnangud viie puuliigi kolmele erineva rinnasdiameetriga puistule.

had more biomass for $G H$ due to denser wood. Fitzroya cupressoides forests from Alerce Costero National Park (UrrutiaJalabert et al., 2015) had less biomass than predicted by the model (2) due to smaller wood density. After stand form factor conversion the difference in forest biomass in 
respect to $\mathrm{GH}$ is mainly determined by the organic matter density. For example, the mean wood density in old-growth Atlantic forest sample plots 1,2 and 3 was 0.655 , 0.661 and $0.711 \mathrm{~g} / \mathrm{cm}^{3}$ and the differences of aggregated tree biomass from the standlevel model (2) were respectively $41 \mathrm{t} / \mathrm{ha}$, $39 \mathrm{t} / \mathrm{ha}$ and $69 \mathrm{t}$ / ha (Figure 5).

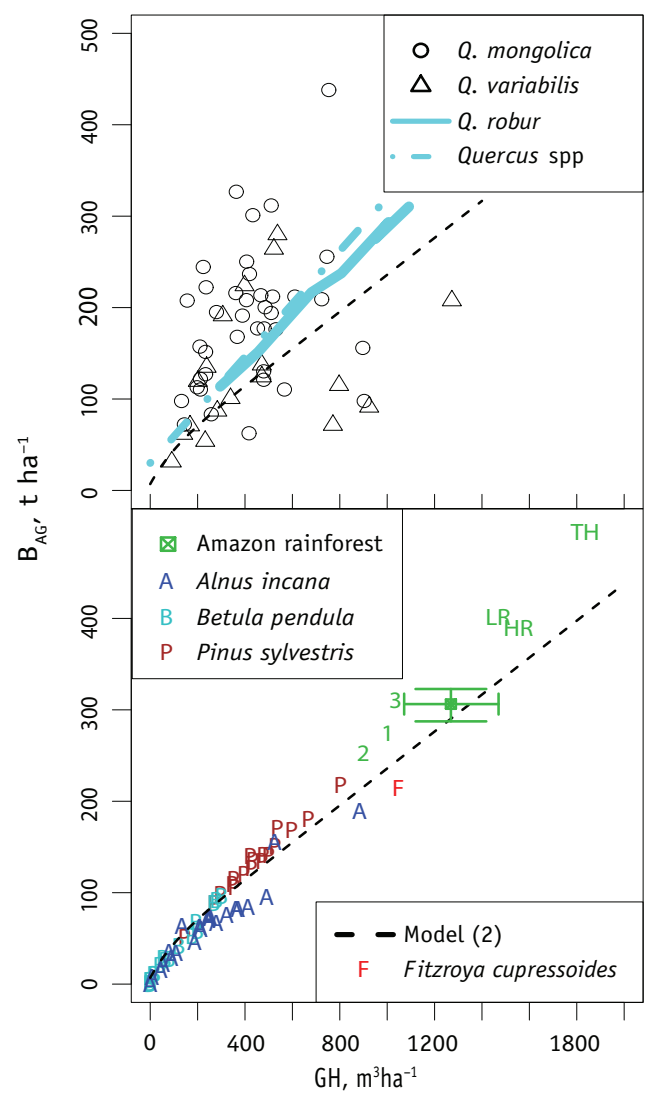

Figure 5. Upper: Oak forest data from Li et al. (2012), Orzeł et al. (2006) model for Quercus robur and Cannell (1984) model for Quercus spp. Lower: The green point with confidence limits is an old-growth Amazon rainforest (Rice et al., 2004). "1", "2", " 3 " stand for old-growth Atlantic forest; $H R$ is high restinga, LR is low restinga and $\mathrm{TH}$ is tahuampa forest. " $\mathrm{F}$ " is plot $\mathrm{AC1}$ from Urrutia-Jalabert et al. (2015).

Joonis 5. Kirjanduses avaldatud puistute maapealse osa biomassi võrdlus mudeliga (2).
The third set of biomass data was from Estonia and Poland. The model (2) underestimated biomass for Scots pine stands by $10.5 \mathrm{t} / \mathrm{ha}$, overestimated biomass in young silver birch stands by $4 \mathrm{t} / \mathrm{ha}$ and overestimated biomass in grey alder stands by $12.8 \mathrm{t} / \mathrm{ha}$. The biomass of grey alder stands had a declining trend with increasing $G H$ except for two sample plots with biggest biomass (Figure 5). Since wood density for the stands was independent on stand structure variables (Uri et al., 2014), the smaller gain is probably caused by changes in form factor. Similar decreasing trend of form factor with increasing forest biomass was observed in FGN forests. Compared to the generic model (Table 1) silver birch model (Table A5.1) predicts more biomass compared to grey alder model for the same $\mathrm{GH}$. The difference is determined mainly by wood density and in some extent by form factor of grey alder and silver birch stands.

\section{Discussion}

We estimated parameters for a linear regression model in similar to Cannell (1984) by using biomass data from literature. Wulder et al. (2008) constructed a linear biomass model $B_{A G}=29.2883+0.4123 V$ for Canada based on stem merchantable volume and presented also individual models for deciduous, coniferous and mixed forests. Wulder et al. (2008) do not give confidence intervals for the model parameter estimates. If we assume a mean stem form factor $F \approx 0.5$ (Krigul, 1972; Tappo, 1982) and substitute $G H=V / F$, then the literature data-based model (1) and the model of Wulder et al. (2008) are similar. The simple linear model (1) overestimated biomass in young stands, but this was compensated by adding a start correction component and the model was used in further analysis. Biomass measurement data from Estonia and Poland were used to estimate model (2) parameters for grey alder stands 
and silver birch stands. The models are convenient to use in practice, since $G$ and $H$ are easy to measure standard variables in forest inventories. A possible application of the proposed generic model could be estimating biomass using remotely sensed tree height (Lefsky, 2010; Simard et al., 2011) and basal area from simple field assessments using for instance Bitterlich samples (Bitterlich, 1948), aggregated and gap-filled forest inventory data (Moreno et al., 2016) or assumptions using management plans or yield tables. However, the stand-level GH-based model structure may need to be enhanced in next studies to explicitly include density $\left(\mathrm{g} / \mathrm{cm}^{3}\right)$ and stand form factor for better local estimates. The species independent $G H$-based generic model may yield biased estimates when applied in forests where wood density or form factor differs systematically from the model (2) data set.

The generic model provided a good basis to verify Scandinavian single-tree biomass models in Estonia using forest inventory data from Estonian Network of Forest Research sample plots. From the two examined tree biomass models Repola (2008, 2009) gives slightly smaller estimates compared to Marklund (1988) model. The data for Marklund (1988) model are from 1983 and Repola models $(2008,2009)$ are based on data from years 1983-2003. With the 20 years, growth conditions are changed due to rising $\mathrm{CO}_{2}$ level and global warming influencing northern latitudes (Myneni et al., 1997) and the Marklund (1988) models may give already biased estimates in Estonian forests. In similar to boreal forests, old-growth tropical forest trees may be growing also more in the last decades, increasing net primary productivity and altering forest dynamics (Lewis et al., 2009; Brienen et al., 2015), although it is controversial whether it is due to $\mathrm{CO}_{2}$ level or past disturbances (Clark, 2004; Muller-Landau, 2009) and the rate of growth increase has decreased after 2000 in Amazon forest (Brienen et al., 2015). Probably, the param- eters for tree-level regression models must be estimated based on new samples to account for changed growth conditions if the models are used for change detection in biomass accounting.

Two competition indices gave somewhat controversial results on dependence of biomass accumulation as a function of competition between trees at stand level when above-ground biomass was used as dependent variable. One reason may be that the FGN-forests are managed and the current structure of the forests does not always reflect past influences of competition. Another reason could be that the $C I_{\text {Hegyi }}$ was a function of mean distance between trees, but $C I_{L T J}$ is dependent mainly on basal area. According to $\mathrm{CI}_{\mathrm{Hegyi}}$, the more recent model from Repola $(2008,2009)$ depends more on competition between trees than the older biomass model from Marklund (1988) which seems not to have so much feedback from competition when looking at the difference of aggregated tree biomass from model (2) $B_{A G(2)}$. The shape of the relationship depends somewhat on the reference model, however, the model (2) or the original model of Cannell (1984) as reference give similar results. However, the stronger dependence of $B_{A G(R)}$ on competition was not so evident when absolute values of biomass were analysed. Even more, according to $C I_{L T J}$ competition described more variability of $B_{A G(M)}-B_{A G(2)}$. However, both of the biomass models produced smaller biomass estimates for stands where selfthinning process was weaker according to Nilson's $C I_{L T J}$ index. This means for forest management perspective that less trees must be harvested in thinning cuttings to retain sustainable rate of competition for the forest stands where biomass storage is the main purpose. Similar relationship was presented by Luyssaert et al. (2008) in their Figure 2 regarding stand density and biomass. The share of tree crown mass from total above-ground biomass is also an indicator of competition. Open grown trees have wider crowns than closed canopy 
trees (Hasenauer, 1997) as a result of smaller competition. Kilpeläinen et al. (2010) analysed biomass data of different Norway spruce provenance clones and found that Repola (2009) model had smaller estimation error compared to Marklund (1988) model which substantially overestimated biomass of branches.

While trees grow, each individual requires more space to survive and mortality (Laarmann et al., 2009) decreases the number of trees per unit area. When the trees grow taller, stand form factor decreases. Both processes influence biomass accumulation in forest stand per unit area. Stand form factor can somewhat be compensated by the increased amount of branches, however, trees with smaller branches and faster self-pruning have better stem-wood quality. Little is known about age dependence of wood density change which may compensate the mortality and forest form factor decrease in some extent. The changes are related to cambial age, plant water distribution maintenance and creating an optimal mechanical structure (Lachenbruch et al., 2011) which results in smaller tree ring width (MacPeak, 1990) and denser outerwood compared to corewood. Wood density is dependent also on site fertility and denser wood e.g. in Scots pine forests can be found on sites of medium fertility (Kask \& Pikk, 2009).

Biomass density and tree form factor are accounted directly or indirectly in local allometric regression models, since the properties of sample trees are reflected also in the model parameters. This may be the reason why allometric models of tree biomass from different countries give substantially variable estimates for a tree (Neumann et al., 2016). However, there is no reason why a tree growing near the border of two countries shall have different biomass estimates depending on country. This study showed that the differences between the countryspecific tree biomass models propagate further to stand level and the range of estimated biomass is wide $( \pm 30-50 \%$ of mean) for a stand. Compared to the other models used in Europe, Repola $(2008,2009)$ models give systematically smaller above-ground biomass estimates for big trees in FORMIT stands. In some cases, a biomass model for individual tree component may fail as appeared with branch mass models used for Norway spruce in Spain. As expected with the denser wood, FORMIT oak and beech stands had more biomass per unit area than predicted by the generic model. However, there was still substantial scatter in biomass estimates made with the countryspecific models which can partly explained with the influence of data used for developing the regression models.

The fit of biomass of the simulated stands with the generic model (2) could probably be improved by accounting for possible differences in form factor of the European models. However, not all of the biomass models were based on volume to mass conversion and we did not have volume models for all the countries to estimate form factor for the trees in a uniform manner.

The generic model was well in agreement with data from tropical forests after transforming stand form factor where necessary data for the conversion were available. On the other hand, we found that the stand-level model (2) is not well applicable for the forest data where only arithmetic mean estimates for $D$ and $H$ are available as appeared with oak stand data from Korea. However, we do not know the form factor for each individual stand shown in Li et al. (2012). It is also possible that stand form factor, wood density and proportion of bark in oak stands have a large natural variation in Korea. While such published biomass datasets are still informative for further studies, it is recommended to include the descriptive forest variables $(V$, $\left.F, G, N, H_{\text {Lorey }}\right)$ that allow to apply stand level GH-based models. On the other hand, Chave et al. (2015) published a complete database of single tree measurements used to construct pan-tropical biomass model. A similar database with tree biomass sam- 
ples from Europe could be useful to improve and harmonize carbon calculation methods.

\section{Conclusions}

- If growth conditions change, then single tree biomass models based on more than 20 years old data may be outdated.

- More biomass per unit area basis can be stored into forest stand when competition between trees is strong. Thinning cuttings must be conservative in the forests where carbon storage is main target and aimed to stipulate growth of species with denser wood or longer biological age.

- The introduced generic model allows biomass estimates independent on species using remote sensing data (e.g. height from airborne laser scanning data) and/or simple field measurement or assumptions (e.g. basal area).

- A common database of forest biomass measurements from Europe in similar to pan-tropical tree measurement data may be helpful harmonise carbon accounting methods.

Acknowledgements. This work is part of the project 'The carbon dynamics in Estonian forests affected by sustainable management' (Estonian Ministry of Education and Research grant no IUT21-4). We further want to acknowledge support from FORMIT ('Enhancing the FORest MITigation potential of European Forests') - financed by DG Research and Innovation within the Seventh Framework Program. The research was also supported by the Polish National Science Center in the years 2013-2016. Authors thank Professor Jonathan Onyekwelu and Professor Yo Whan Son for explaining details of their publications. Dr Asko Noormets and Dr Jérôme Chave pointed out useful references to publications. Estonian Network of Forest Research Plots is supported by the Esto- nian State Forest Management Centre and the Estonian Environmental Investment Centre. Authors thank reviewers for their comments.

\section{References}

Agarmaa, M. 2015. The above-ground biomass and the effect of drainage on trees radial growth increment in Scots pine (Pinus sylvestris) stands growing in Myrtillus drained swamp site type. (Mustika-kõdusoo kasvukohatüübi männikute (Pinus sylvestris L.) maapealne biomass ja kuivenduse mõju puude jämeduskasvule). MSc Thesis, Estonian University of Life Sciences. 29 pp. (In Estonian).

Aosaar, J., Uri, V. 2008. Biomass production of grey alder, hybrid alder and silver birch stands on abandoned agricultural land. - Forestry Studies / Metsanduslikud Uurimused, 48, 53-66.

Aosaar, J., Varik, M., Lõhmus, K., Ostonen, I., Becker, H., Uri, V. 2013. Long-term study of above- and below-ground biomass production in relation to nitrogen and carbon accumulation dynamics in a grey alder (Alnus incana (L.) Moench) plantation on former agricultural land. - European Journal of Forest Research, 132, 737-749.

Arumäe, T., Lang, M. 2016. A validation of coarse scale global vegetation height map for biomass estimation in hemiboreal forests in Estonia. Baltic Forestry, 22(2). (In press).

Asner, G.P. Mascaro, J., Muller-Landau, H.C., Vieilledent, G., Vaudry, R., Rasamoelina, M., Hall, J.S., van Breugel, M. 2012. A universal airborne LiDAR approach for tropical forest carbon mapping. - Oecologia, 168, 1147-1160.

Bartelink., H.H. 1997. Allometric relationships for biomass and leaf area of beech (Fagus sylvatica L). - Annales des sciences forestières, INRA/EDP Sciences, 54, 39-50.

Bitterlich, W. 1948. The introduction of angle count sampling into forestry. (Die Winkelzaehlprobe). Allgemeine Forst- und Holzwirtschaftliche Zeitung, 59(1-2), 4-5. (In German).

Bormann, F.H., Likens, G.E. 1992. Pattern and process in a forested ecosystem: Disturbance, development, and the steady state based on the Hubbard Brook ecosystem study. New York, Springer-Verlag.

Brienen, R.J.W., Phillips, O.L., Feldpausch, T.R., Gloor, E., Baker, T.R., et al. 2015. Long-term decline of the Amazon carbon sink. - Nature, 519, 344-348.

Bronisz, K., Zasada, M. 2016. Simplified empirical formulas to determine the dry biomass of aboveground components of trees for Scots pine. (Uproszczone wzory empiryczne do określania suchej biomasy nadziemnej części drzew i ich komponentów dla sosny zwyczajnej). - Sylwan, 160(4), 277-283. (In Polish). 
Cannell, M.G.R. 1982. World forest biomass and primary production data. London, Academic Press. 391 pp. [WWW document]. - URL ftp://daac. ornl.gov/data/global_vegetation/biomass_allocation/comp/ [Accessed 8 July 2016].

Cannell, M.G.R. 1984. Woody biomass of forest stands. - Forest Ecology and Management, 8, 299-313.

Chave, J., Andalo, C., Brown, S., Cairns, M.A., Chambers, J.Q., Eamus, D., Fölster, H., Fromard, F., Higuchi, N., Kira, T., Lescure, J-P., Nelson, B.W., Ogawa, H., Puig, H., Riéra, B., Yamakura, T. 2005. Tree allometry and improved estimation of carbon stocks and balance in tropical forests. - Oecologia, 145, 87-99.

Chave, J., Coomes, D.A., Jansen, S., Lewis, S.L., Swenson, N.G., Zanne, A.E. 2009. Towards a worldwide wood economics spectrum. - Ecology Letters, 12(4), 351-366.

Chave, J., Réjou-Méchain, M., Búrquez, A., Chidumayo, E., Colgan, M.S., Delitti, W.B.C., Duque, A., Eid, T., Fearnside, P.M., Goodman, R.C., Henry, M., Martínez-Yrízar, A., Mugasha, W.A., Muller-Landau, H.C., Mencuccini, M., Nelson, B.W., Ngomanda, A., Nogueira, E.M., Ortiz-Malavassi, E., Pélissier, R., Ploton, P., Ryan, C.M., Saldarriaga, J.G., Vieilledent, G. 2015. Improved allometric models to estimate the aboveground biomass of tropical trees. - Global Change Biology, 20, 3177-3190.

Clark, D.A. 2004. Sources or sinks? The responses of tropical forests to current and future climate and atmospheric composition. - Philosophical Transactions of the Royal Society of London. Series B: Biological Sciences, 359, 477-491.

Contreras, M.A., Affleck, D., Chung, W. 2011. Evaluating tree competition indices as predictors of basal area increment in western Montana forests. - Forest Ecology and Management, 262, 1939-1949.

DeBell, D.S., Whitesell, C.D., Schubert, T.H. 1985. Mixed plantations of Eucalyptus and leguminous trees enhance biomass production. - Res. Paper PSW-RP-175. Berkeley, CA: Pacific Southwest Forest and Range Experiment Station, Forest Service, U.S. Department of Agriculture. 6 pp.

Enquist, B.J., Niklas, K.J. 2002. Global allocation rules for patterns of biomass partitioning across seed plants. - Science, 295, 1517-1520.

Finèr, L., Mannerkoski, H., Piirainen, S., Starr, M. 2003. Carbon and nitrogen pools in an old-growth, Norway spruce mixed forest in eastern Finland and changes associated with clear-cutting. - Forest Ecology and Management, 174, 51-63.

Forrester, D.I, Bauhus, J., Khanna, P.K. 2004. Growth dynamics in a mixed-species plantation of Eucalyptus globulus and Acacia mearnsii. - Forest Ecology and Management, 193, 81-95.

Frey, T. 2009. Stand structure links up canopy processes and forest management. - Forestry Studies / Metsanduslikud Uurimused, 51, 40-48.
Goodman, R.C., Phillips, O.L., Torres, D.C., Freitas, L., Cortese, S.T., Monteagudo, A., Baker, T.R. 2013. Amazon palm biomass and allometry. Forest Ecology and Management, 310, 994-1004.

Harrison, R.B., Terry, T.A., Licata, C.W., Flaming, B.L, Meade, R., Guerrini, I.A., Strahm, B.D., Xue, D., Lolley, M.R., Sidell, A.R., Wagoner, G.L., Briggs, D., Turnblom, E.C. 2009. Biomass and stand characteristics of a highly productive mixed Douglasfir and western hemlock plantation in coastal Washington. - Western Journal of Applied Forestry, 24, 180-186.

Hasenauer, H. 1994. A individual tree growth simulator for uneven-aged spruce - pine and beech spruce mixed forest stands. (Ein Einzelbaumwachstumssimulator für ungleichaltrige FichtenKiefern- und Buchen-Fichtenmischbestände). Forstliche Schriftenreihe der Universität für Bodenkultur. Wien, Österreichische Gesellschaft für Waldökosystemforschung und Experimentelle Baumforschung. Band 8, 152 p. (In German).

Hasenauer, H. 1997. Dimensional relationships of open-grown trees in Austria. - Forest Ecology and Management, 96, 197-206.

Hayashi, R., Kershaw, J., Weiskittel, A. 2015. Evaluation of alternative methods for using LiDAR to predict aboveground biomass in mixed species and structurally complex forests in northeastern North America. - Mathematical and Computational Forestry \& Natural-Resource Sciences, 7, 49-65.

Hegyi, F. 1974. A simulation model for managing jackpine stands. - Fries, J. (ed.). Proceedings of IUFRO meeting S4.01.04 on Growth models for tree and stand simulation. Stockholm, Royal College of Forestry.

Helmisaari, H.S., Makkonen, K., Kellomäki S., Valtonen, E., Mälkönen, E. 2002. Below- and aboveground biomass, production and nitrogen use in Scots pine stands in eastern Finland. - Forest Ecology and Management, 165, 317-326.

Henry, M., Bombelli, A., Trotta, C., Alessandrini, A., Birigazzi, L., Sola, G., Vieilledent, G., Santenoise, P., Longuetaud, F., Valentini, R., Picard, N., SaintAndré, L. 2013. GlobAllomeTree: international platform for tree allometric equations to support volume, biomass and carbon assessment. - iForest, 6, 320-330.

Jaakkola, T., Mäkinen, H., Saranpää, P. 2005. Wood density in Norway spruce: changes with thinning intensity and tree age. - Canadian Journal of Forest Research, 35, 1767-1778.

Johansson, T. 1999a. Biomass equations for determining fractions of European aspen growing on abandoned farmland and some practical implications. - Biomass and Bioenergy, 17, 471-480.

Johansson, T. 1999b. Biomass production of Norway spruce (Picea abies (L.) Karst.) growing on abandoned farmland. - Silva Fennica, 33, 261-280. 
Johansson, T. 2007. Biomass production and allometric above- and below-ground relations for young birch stands planted at four spacings on abandoned farmland. - Forestry, 80, 41-52.

Johansson, T. 2013. Biomass production of hybrid aspen growing on former farm land in Sweden. Journal of Forestry Research, 24, 237-246.

Johnston, D.C. 1977. Estimating lodgepole pine biomass. - Theses, Dissertations, Professional Papers. Paper 2237.

Jung, S.Y., Ju, N.G., Lee, K.S., Yoo, B.O., Park, Y.B., Yoo, S.B., Park, P.J. 2015. Thinning intensity and growth response in a Quercus acuta stand. - Journal of Korean Forest Society, 104, 536-542.

Kadak, M. 2015. Above-ground biomass production in downy birch stands in drained peatland. (Jänesekapsa-kõdusoo kasvukohatüübi sookaasikute maapealne bioproduktsioon). MSc Thesis, Estonian University of Life Sciences. 30 pp. (In Estonian).

Kask, R. 2003. Physical and mechanical properties of Scots pine (Pinus sylvestris L.) on bilberry and cowberry forest site types. (Hariliku männi (Pinus sylvestris L.) puidu mehhaanilised ja füüsikalised omadused pohla ja mustika metsakasvukohatüübis). MSc Thesis, Estonian Agricultural University. (In Estonian).

Kask, R., Pikk, J. 2009. Second thinning Scots pine wood properties in different forest site types in Estonia. - Baltic Forestry, 15, 97-104.

Kilpeläinen, A., Routa, J., Peltola, H., Zubizarreta Gerendiain, A., Pulkkinen, P., Kellomäki, S. 2010. Effects of genetic entry and competition on above ground biomass production of Norway spruce grown in southern Finland. - Forest Ecology and Management, 259, 2327-2332.

Kittenberger, A. 2003. Generation of the tree distribution patterns. (Generierung von Baumverteilungsmustern). Diploma thesis. Universität für Bodenkultur. Wien, Austria. 79 pp. (In German).

Kiviste, A., Hordo, M., Kangur, A., Kardakov, A., Laarmann, D., Lilleleht, A., Metslaid, S., Sims, A., Korjus, H. 2014. Monitoring and modeling of forest ecosystems: the Estonian Network of Forest Research Plots. - Forestry Studies / Metsanduslikud Uurimused, 62, 26-38.

Klopf, M., Thurnher, C., Hasenauer, H., 2011. Moses Framework user guide. (Benutzerhandbuch MosesFramework). Universität für Bodenkultur. Wien, Austria. 124 pp. (In German).

Kõlli, R. 2002. Productivity and humus status of forest soils in Estonia. - Forest Ecology and Management, 171, 169-179.

Kõlli, R., Kanal, A. 2010. The management and protection of soil cover: an ecosystem approach. - Forestry Studies / Metsanduslikud Uurimused, 53, 25-34.

Krigul, T. 1972. Forest mensuration. (Metsatakseerimine). Tallinn, Valgus. 348 pp. (In Estonian).

Laarmann, D., Korjus, H., Sims, A., Stanturf, J.A., Kiviste, A., Köster, K. 2009. Analysis of forest natural- ness and tree mortality patterns in Estonia. - Forest Ecology and Management, 258, S187-S195.

Lachenbruch, B., Moore, J.R., Evans, R. 2011. Radial variation in wood structure and function in woody plants, and hypotheses for its occurrence. Meinzer, F.C., Lachenbruch, B., Dawson, T.E. (eds.). Size- and age-related changes in tree structure and function. Tree Physiology 4. Springer, 121-164

Larson, P. 1963. Stem form development of forest trees. - Forest Science Monograph 5, 41 pp.

Lefsky, M. 2010. A global forest canopy height map from the Moderate Resolution Imaging Spectroradiometer and the Geoscience Laser Altimeter System. - Geophysical Research Letters, 37(15), $1-5$.

Lewis, S.L., Lopez-Gonzalez, G., Sonke, B. et al. 2009. Increasing carbon storage in intact African tropical forests. - Nature 457, 1003-1006.

Li, X., Son, Y.M., Lee, K.H., Kim, R.H., Yi, M.J., Son, Y. 2012. Notes on the biomass expansion factors of Quercus mongolica and Quercus variabilis forests in Korea. - Journal of Ecology and Field Biology, 35, 243-249.

Lilleleht, A. 2011. Relationships between stand volume growth and composition in mixed stands dominated by Scots Pine (Pinus sylvestris L.). Forestry Studies / Metsanduslikud Uurimused, $54,18-27$.

Lilleleht, A., Sims, A., Pommerening, A. 2014. Spatial forest structure reconstruction as a strategy for mitigating edge-bias in circular monitoring plots. - Forest Ecology and Management, 316, 47-53.

Lumbres, R.I.C., Lee, Y.J., Choi, H.S., Kim, S.Y., Jang, M.N., Abino, A.C., Seo, Y.O., Kim, C.S., Park, J.H. 2014. Comparative analysis of four stem taper models for Quercus glauca in Mount Halla, Jeju Island, South Korea. - Journal of Mountain Science, 11, 442-448.

Luyssaert, S., Schulze, E.D., Börner, A., Knohl, A., Hessenmöller, D., Law, B.E., Ciais, P., Grace, J. 2008. Old-growth forests as global carbon sinks. Nature, 455, 213-215.

MacPeak, M., Burkart, L., Weldon, D. 1990. Comparison of grade, yield, and mechanical properties of lumber produced from young fast-grown and older slow-grown planted slash pine. - Forest Products Journal, 40(1), 11-14.

Marklund, L.G. 1988. Biomass functions for pine, spruce and birch in Sweden. Swedish University of Agricultural Sciences. Department of Forest Survey. Report 45, 71 pp.

Mikšys, V., Varnagiryte-Kabasinskiene, I., Stupak, I., Armolaitis, K., Kukkola, M., Wójcik, J. 2007. Above-ground biomass functions for Scots pine in Lithuania. - Biomass and Bioenergy, 31, 685692.

Mitt, R., Padari, A., Samsonov, M. 2014. Modelling of woody biomass on electricity pylons. - Forestry Studies / Metsanduslikud Uurimused, 60, 44-56. 
Mõistus, M., Lang, M. 2015. Leaf area index mapping with optical methods and allometric models in SMEAR flux tower footprint at Järvselja, Estonia. Forestry Studies / Metsanduslikud Uurimused, 63, 1-15.

Möll, H. 2015. Biomass production and carbon budget in 40-year-old downy birch (Betula pubescens) stands growing in Oxalis drained swamp sitetype. (Biomassi produktsioon ja süsiniku bilanss 40-aastases sookaasikus (Betula pubescens) jänesekapsa-kõdusoo kasvukohatüübis). MSc Thesis, Estonian University of Life Sciences. 30 pp. (In Estonian).

Moreno, A., Neumann, M., Hasenauer, H. 2016. Optimal resolution for linking remotely sensed and forest inventory data in Europe. - Remote Sensing of Environment, 183, 109-119.

Muller-Landau, H.C. 2009. Carbon cycle: sink in the African jungle. - Nature, 457, 969-970.

Myneni, R.B., Keeling, C.D., Tucker, C.J., Asrar, G., Nemani. R.R. 1997. Increased plant growth in the northern high latitudes from 1981 to 1991 . - Nature, 386, 698-702.

Nabuurs, G.J., Masera, O., Andrasko, K., BenitezPonce, P., Boer, R., Dutschke, M., Elsiddig, E., Ford-Robertson, J., Frumhoff, P., Karjalainen, T., Krankina, O., Kurz, W.A., Matsumoto, M., Oyhantcabal, W., Ravindranath, N.H., Sanz Sanchez, M.J., Zhang, X. 2007. Forestry. - Metz, B., Davidson, O.R., Bosch, P.R., Dave, R., Meyer, L.A. (eds). Climate Change 2007: Mitigation. Contribution of Working Group III to the Fourth Assessment Report of the Intergovernmental Panel on Climate Change. Cambridge University Press, Cambridge, United Kingdom and New York, NY, USA.

Nebel, G., Dragsted, J., Vega, A.S. 2001. Litter fall, biomass and net primary production in flood plain forests in the Peruvian Amazon. - Forest Ecology and Management, 150, 93-102.

Neumann, M., Moreno, A., Mues, V., Härkönen, S., Mura, M., Bouriaud, O., Lang, M., Achten, W.M.J., Thivolle-Cazat, A., Bronisz, K., Merganič, J., Decuyper, M., Alberdi, I., Astrup, R., Mohren, F., Hasenauer, H. 2016. Comparison of carbon estimation methods for European forests. - Forest Ecology and Management, 361, 397-420.

Newman, G.S., Arthur, M.A., Muller, R.N. 2006. Above- and belowground net primary production in a temperate mixed deciduous forest. - Ecosystems, 9, 317-329.

Nilson, A. 2005. Fitness of allometric equation $\mathrm{N}=$ $\mathrm{aD}^{\mathrm{b}}$ and equation $\mathrm{N}=(\mathrm{a}+\mathrm{bD})^{-2}$ for modelling the dependence of the number of trees $\mathrm{N}$ on their mean diameter D in yield tables. - Forestry Studies / Metsanduslikud Uurimused, 43, 159-172.

Nilson, T., Peterson, U. 1994. Age dependence of forest reflectance - analysis of main driving factors. Remote Sensing of Environment, 48, 319-331.

Onyekwelu, J.C. 2004. Above-ground biomass production and biomass equations for even-aged
Gmelina arborea (ROXB) plantations in southwestern Nigeria. - Biomass and Bioenergy, 26, $39-46$.

Onyekwelu, J.C. 2007. Growth, biomass yield and biomass functions for plantation-grown Nauclea diderrichii (de Wild) in the humid tropical rainforest zone of south-western Nigeria. - Bioresource Technology, 98, 2679-2687.

Orzeł, S., Ochal, W., Forgiel, M., Socha, J. 2006. Biomass and annual production of oak stands in the Niepołomicka Forest. (Biomasa i roczna produkcja drzewostanów dębowych Puszczy Niepołomickiej). - Sylwan 150(5), 30-43. (In Polish).

Padari, A. 1999. Timber assessment in forest stands. (Kasvava metsa hindamine. Sortimendid ja rikked). - Pidev metsakorraldus, 32, 37-43. (In Estonian).

Park, I.H., Son, Y., Kim, D.Y., Jin, H.O., Yi, M.Y., Kim, R.H., Hwang, J.O. 2005. Biomass and production of a naturally regenerated oak forest in southern Korea. - Ecological Research, 20, 227-231.

Pastorella, F., Paletto, A. 2014. Biomass allocation in natural regeneration of Fagus sylvatica and Picea abies trees in Italian Alps. - Forestry Studies / Metsanduslikud Uurimused, 61, 35-46.

Peichl, M., Arain, A.M. 2006. Above- and belowground ecosystem biomass and carbon pools in an age-sequence of temperate pine plantation forests. - Agricultural and Forest Meteorology, 140, 51-63.

Qiong, Z., Xing-Yu, L., De-Hui. Z. 2011. Aboveground biomass and nutrient allocation in an agesequence of Larix olgensis plantations. - Journal of Forestry Research, 22, 71-76.

Repola, J. 2008. Biomass equations for birch in Finland. - Silva Fennica, 42, 605-624.

Repola, J. 2009. Biomass equations for Scots pine and Norway spruce in Finland. - Silva Fennica, 43, 625-647.

Rice, A.H., Pyle, E.H., Saleska, S.R., L. Hutyra, L., Palace, M., Keller, M., de Camargo, P.B., Portilho, K., Marques,D.F., Wofsy, S.C. 2004. Carbon balance and vegetation dynamics in an old-growth Amazonian forest. - Ecological Applications, 14, S55-S71.

Rolim, S.G., Machado R.E., Pillar, V.D. 2016. - Divergence in a neo-tropical forest during 33 years of succession following clear-cutting. - Journal of Vegetation Science. (In press).

Saarmann, E., Veibri, U. 2006. Wood science. (Puiduteadus). Tartu, Vali Press OÜ. 74 pp. (In Estonian).

Schietti, J., Martins, D., Emilio, T., Souza, P.F., Levis, C., Baccaro, F.B., da Veiga Pinto, J.L.P., Moulatlet, G.M., Stark, S.C., Sarmento, K., de Araújo, R.N.O., Costa, F.R.C., Schöngart, J., Quesada, C.A., Saleska, S.R., Tomasella, J., Magnusson, W.E. 2016. Forest structure along a $600 \mathrm{~km}$ transect of natural disturbances and seasonality gradients in centralsouthern Amazonia. - Journal of Ecology, 104, 1335-1346. 
Simard, M., Pinto, N., Fisher, J.B., Baccini, A. 2011. Mapping forest canopy height globally with spaceborne lidar. - Journal of Geophysical Research, 116(G4), G04021. [WWW document]. URL http://doi.org/10.1029/2011JG001708 [Accessed 12 July 2016].

Sims, A., Kiviste, A., Hordo, M., Laarmann, D., Gadow, K. v. 2009. Estimating tree survival: a study based on the Estonian Forest Research Plots Network. - Annales Botanici Fennici, 46, 336-352.

Son,Y., Park, I.H., Yi, M.J., Kim, D.Y., Jin, H.O., Kim, R.H., Hwang, J.O. 2004. Biomass, production and nutrient distribution of a natural oak forest in central Korea. - Ecological Research, 19, 21-28.

Stephenson, N.L., Das, A.J., Condit R., Russo, S.E., Baker, P. J., Beckman N.G., Coomes D.A., Lines, E.R., et al. 2014. Rate of tree carbon accumulation increases continuously with tree size. - Nature, 507, 90-93.

Tappo, E. 1982. Mean characteristics of forest stands in Estonia by dominant species, site fertility and age. (Eesti NSV puistute keskmised takseertunnused puistu enamuspuuliigi, boniteedi ja vanuse järgi). Tallinn, Eesti NSV Põllumajandusministeeriumi Informatsiooni ja Juurutamise Valitsus. 72 pp. (In Estonian).

Ter-Mikaelian, M.T., Korzukhin, M.D. 1997. Biomass equations for sixty-five North American tree species. - Forest Ecology and Management, 97, 1-24.

Tobin, B., Nieuwenhuis, M. 2007. Biomass expansion factors for Sitka spruce (Picea sitchensis (Bong.) Carr.) in Ireland. - European Journal of Forest Research, 126, 189-196.

Uri, V., Aosaar, J., Varik, M., Becker, H., Ligi, K., Padari, A., Kanal, A., Lõhmus, K. 2014. The dynamics of biomass production, carbon and nitrogen accumulation in grey alder (Alnus incana (L.) Moench) chronosequence stands in Estonia. - Forest Ecology and Management, 327, 106-117.

Uri, V., Varik, M., Aosaar, J., Kanal, A., Kukumägi, M., Lõhmus, K. 2012. Biomass production and carbon sequestration in a fertile silver birch (Betula pendula Roth) forest chronosequence. - Forest Ecology and Management, 267, 117-126.
Urrutia-Jalabert, R., Malhi, Y., Lara, A. 2015. The oldest, slowest rainforests in the world? Massive biomass and slow carbon dynamics of Fitzroya cupressoides temperate forests in Southern Chile. PLoS One 10(9):e0137569.

Vanclay, J.K. 1994. Modelling forest growth and yield: Applications to mixed tropical forests. CAB International, Wallingford, U.K. 280 pp.

Vares, A., Lõhmus, K., Truu, M., Truu, J., Tullus, H., Kanal, A. 2004b. Productivity of black alder (Alnus glutinosa (L.) Gaertn.) plantations on reclaimed oil-shale mining detritus and mineral soils in relation to rhizosphere conditions. - Oil Shale, 21, 43-58.

Vares, A., Tullus, H., Lõhmus, K. 2004a. Aboveground biomass, production and main mineral nutrients in young stands of black alder (Alnus glutinosa (L.) Gaertn.) of different density. - Forestry Studies / Metsanduslikud Uurimused, 40, 165-175.

Varik, M., Aosaar, J., Uri, V. 2009. Biomass production in silver birch stands in Oxalis site type. - Forestry Studies / Metsanduslikud Uurimused, 51, 5-16.

Võsu, A. 2012. Biomass production in 20-45 years old grey alder (Alnus incana (L.) Moench) stands. (Hall-lepikute bioproduktsioon 20-45 aastastes puistutes). - MSc Thesis, Estonian University of Life Sciences. 34 pp. (In Estonian).

Wulder, M.A., White, J.W., Fournier, R.A., Luther, J.E., Magnussen, S. 2008. Spatially explicit large area biomass estimation: Three approaches using forest inventory and remotely sensed imagery in a GIS. - Sensors, 8, 529-560.

Zasada, M., Bijak, S., Bronisz, K., Bronisz, A., Gawęda, T. 2014. Biomass dynamics in young silver birch stands on post-agricultural lands in central Poland. - Drewno, 192, 29-39.

Zianis, D., Muukkonen, P., Mäkipää, R., Mencuccini, M. 2005. Biomass and stem volume equations for tree species in Europe. - Silva Fennica Monographs 4, $63 \mathrm{pp}$. 
Appendix A1. Description of stands used for model construction and analysis.

Lisa A1. Mudeli koostamiseks kasutatud empiiriline andmestik.

Table A1.1. Description of stands used to estimate parameters for above-ground biomass models (1) and (2). For some stands particular details were collected from several publications.

Tabel A1.1. Puistute andmed, mille põhjal hinnati mudelite (1) ja (2) parameetrid.

\begin{tabular}{|c|c|c|c|c|c|c|}
\hline $\begin{array}{l}\text { Source } \\
\text { Allikas }\end{array}$ & $\begin{array}{l}\text { Species } \\
\text { Puuliigid }\end{array}$ & $\begin{array}{c}\text { Count } \\
\text { Arv }\end{array}$ & $N$ (trees/ha) & $D(\mathrm{~cm})$ & $H(\mathrm{~m})$ & $B_{A G}(\mathrm{t} / \mathrm{ha})$ \\
\hline $\begin{array}{l}\text { Uri et al. (2012)*, } \\
\text { Varik et al. (2009) }\end{array}$ & Betula pendula & 7 & $305-100000$ & $1.3-31.0$ & $3.4-30.1$ & $25.7-220.5$ \\
\hline Agarmaa $(2015)^{1}$ & Pinus sylvestris & 3 & $620-1020$ & $19.0-25.0$ & $20.0-24.0$ & $111.5-217.7$ \\
\hline Kadak (2015), Möll (2015) ${ }^{2}$ & Betula pubescens & 5 & $768-2752$ & $7.9-17.9$ & $12.0-19.3$ & $47.4-122.0$ \\
\hline Võsu (2012), Uri et al. (2014) & Alnus incana & 11 & $691-6761$ & $7.4-24.8$ & $11.6-23.1$ & $56.1-184.4$ \\
\hline Johansson (2007) & Betula spp. & 16 & $1479-5917$ & $2.7-7.0$ & $4.4-8.2$ & $14.3-63.5$ \\
\hline Vares et al. (2004a, 2004b) & Alnus glutinosa & 5 & $1530-7222$ & $7.6-13.9$ & $9.8-15.1$ & $80.2-100.6$ \\
\hline Aosaar \& Uri (2008) & Betulaceae & 4 & $4850-35600$ & $1.7-4.7$ & $4.4-6.6$ & $15.3-35.4$ \\
\hline Johansson (2013) & Hybrid aspens & 24 & $378-2374$ & $8.5-24.4$ & $10.4-25.8$ & $42.3-219.3$ \\
\hline Johansson (1999a) & Populus tremula & 11 & $5964-46150$ & $1.9-9.2$ & $3.6-15.8$ & $14.3-162.4$ \\
\hline Mikšys et al. (2007) ${ }^{3}$ & Pinus sylvestris & 5 & $727-2893$ & $6.8-23.2$ & $5.1-20.9$ & $40.0-157.0$ \\
\hline Johansson $(1999 b)^{4}$ & Picea abies & 32 & $1133-7600$ & $3.2-21.2$ & $4.1-23.4$ & $6.0-237.4$ \\
\hline Bartelink (1997) & Fagus sylvatica & 6 & $360-9920$ & $3.1-27.9$ & $3.5-22.5$ & $5.9-166.7$ \\
\hline Tobin \& Nieuwenhuis (2007) & Picea sitchensis & 6 & $767-2533$ & $6.0-32.0$ & $3.5-26.7$ & $23.3-403.9$ \\
\hline Qiong et al. (2011) & Larix olgensis & 4 & $519-2220$ & $9.0-25.7$ & $8.9-26.9$ & $59.2-176.6$ \\
\hline Onyekwelu (2004) & Gmelina arborea & 10 & $837-1275$ & $18.4-79.8$ & $15.2-34.3$ & $83.2-394.9$ \\
\hline Kilpeläinen et al.(2010) & Picea abies & 20 & $2500^{* 5}$ & $7.7-14.9$ & $6.8-13.1$ & 43.1-164.9 \\
\hline Helmisaari et al. (2002) & Pinus sylvestris & 3 & $432-7425$ & $1.6-27.3$ & $2.0-20.1$ & $11.2-121.3$ \\
\hline Finèr et al. $(2003)^{6}$ & Mixed coniferous & 1 & 1585 & $10.0-30.8$ & $8.1-20.8$ & 154.0 \\
\hline Forrester et al. (2004) & $\begin{array}{c}\text { Eucalyptus spp., } \\
\text { Acacia spp. }\end{array}$ & 2 & 1515 & $10.0-11.2$ & $10.5-14.1$ & $47.1-75.4$ \\
\hline DeBell, et al. (1985) & $\begin{array}{c}\text { Eucalyptus spp. } \\
\text { mixed }\end{array}$ & 3 & $2024-2200$ & $9,5-15.0$ & $14-19$ & $37.6-95.3$ \\
\hline Cannell (1982) & Various & 31 & $123-12491$ & $3,5-58.5$ & $3.1-43.0$ & $5.7-614.1$ \\
\hline Onyekwelu $(2007)^{7}$ & $\begin{array}{c}\text { Nauclea } \\
\text { diderrichii }\end{array}$ & 9 & $443-667$ & $9.6-29.3$ & $12.9-28.5$ & $32.5-287.7$ \\
\hline Newman et al. $(2006)^{8}$ & Mixed deciduous & 2 & $950-1565$ & $15.7-19.2$ & $26.6-31.9$ & $112.5-113.8$ \\
\hline Johnston (1977) & Pinus contorta & 2 & $1483-2764$ & $9.2-9.9$ & $12.8-14.1$ & $48.5-73.7$ \\
\hline Peichl \& Arain (2006) & Pinus strobus & 3 & $429-1492$ & $15.6-34.6$ & $9.1-20.1$ & $65.5-176.0$ \\
\hline Harrison et al. (2009) ${ }^{10}$ & $\begin{array}{c}\text { Pseudotsuga } \\
\text { menziesii }\end{array}$ & 1 & 615 & 35.6 & 31.6 & 392.4 \\
\hline Park et al. (2005) & Quercus spp. & 3 & $2450-3175$ & $9.0-10.2$ & $10.3-14.3$ & $70.9-100.7$ \\
\hline Son et al. (2004) & Quercus spp. & 3 & $525-1475$ & $12.1-16.6$ & $17.7-18.7$ & 119.9-224.1 \\
\hline
\end{tabular}

* Excluding forest Kooraste2 due to an unrecoverable error causing extremely small wood density according to the data.

1 Needle mass estimated with Marklund (1988) model for pine based on $d$ and $h$.

2 Foliage mass (except for stand JS191-40) estimated with Repola (2008) model.

3 Biomass was estimated from Figure 4.

4 Mean of model tree height for each stand was used instead $H_{40}$ index.

*5 Number of trees per unit area was equal in all stands.

6 Basal area weighted mean $H$ and quadratic mean $D$ and total above-ground biomass was used.

7 Dominant height was used as estimate of $H$.

8 Woody biomass and yearly litter production was used as an estimate for above-ground biomass.

9 Description is for upper layer. Basal area of the lower tree layer $(D<9 \mathrm{~cm})$ is included into analysis.

10 Sum of biomass fractions was used from Table 3 instead of given total. 
Table A1.2. Overview of FGN forests (Kiviste et al., 2014) used in this study. The range of stand inventory variables is in parentheses.

Table A1.2. Uurimuses kasutatud metsa kasvukäiguproovitükkide (Kiviste et al., 2014) valimi üldkirjeldus. Sulgudes on valimi haare.

\begin{tabular}{lcccccc}
\hline $\begin{array}{l}\text { Main species } \\
\text { Peapuuliik }\end{array}$ & $\begin{array}{c}\text { Count } \\
\text { Anv }\end{array}$ & $A$, years & N, trees/ha & $H, \mathrm{~m}$ & $\mathrm{G}, \mathrm{m}^{2} / \mathrm{ha}$ & $H_{100,} \mathrm{~m}$ \\
\hline $\begin{array}{l}\text { Populus tremula } \\
\text { Betula pendula }\end{array}$ & 127 & $55(35-75)$ & $1337(549-2920)$ & $23.2(18.1-28.9)$ & $30.9(18.6-42.5)$ & $28.9(22.9-33.5)$ \\
Picea abies & 193 & $55(22-110)$ & $940(306-2334)$ & $22.0(11.2-33.0)$ & $29.5(8.1-48.8)$ & $30.9(21.5-36.6)$ \\
Alnus glutinosa & 9 & $52(31-70)$ & $1230(780-2467)$ & $21.6(18.7-23.5)$ & $29.9(21.1-37.6)$ & $28.0(26.1-32.5)$ \\
Alnus incana & 3 & $40(35-44)$ & $2266(1386-2769)$ & $18.6(16.4-21.2)$ & $36.1(34.8-38.1)$ & $27.7(26.8-29.2)$ \\
Pinus sylvestris & 675 & $75(20-245)$ & $889(163-3088)$ & $23.1(10.6-35.3)$ & $31.0(7.6-62.9)$ & $27.8(12.0-37.5)$ \\
\hline
\end{tabular}

Appendix A2. Form factor conversion for tropical forests.

Lisa A2. Troopikametsa vormiarvu teisendus.

Trees in natural tropical forests tend to have umbrella-like crowns and biomass is not directly comparable by their $G H$ with forests where crowns are more ellipsoidal. Similar problem occurs with substantial differences in stem form factor found e.g. in Fitzroya cupressoides forest. To make biomass estimates from rainforests comparable by their $G H$ we applied stand form factor conversion based on volume. For example, by excluding $\delta$ from the pantropical model (Chave et al., 2015), volume of stem and branches $v_{s+b}$ for a tropical tree is obtained.

If the parameter for $\mathrm{GH}$ in the model (1) is expressed as $F \delta$, where $F$ is the stand form factor and $\delta=0.5 \mathrm{~g} / \mathrm{cm}^{3}$ is mean wood density, then the stand level model
(1) will be $B_{A G}=25.40+0.422 \delta G H$. Based on stand volume $V_{s+b}$ and stand form factor $F_{\text {conv }}=V_{s+b} / G H$ of a natural tropical forest $\mathrm{GH}_{\text {gen }}=F_{\text {conv }} \mathrm{GH} / 0.422$. For example, oldgrowth Atlantic forest sample plot 1 has $B_{A G}=281 \mathrm{t} / \mathrm{ha}, G=27.9 \mathrm{~m}^{2} / \mathrm{ha}, H=23.5 \mathrm{~m}$, $V_{s+b}=430 \mathrm{~m}^{3} / \mathrm{ha}$ and $F_{\text {conv }}=0.6555$. The stand has $G H=656 \mathrm{~m}^{3} /$ ha and corresponding $G_{\text {gen }}=1019 \mathrm{~m}^{3} /$ ha.

The data for old-growth Amazon rainforest (Rice et al. 2004) did not include live tree volume or wood density data and $H$ was an estimate. By taking an estimate of $\delta=0.64$ from Table 3 in Rice et al. (2004) and taking $H=45 \mathrm{~m}$ and $G=28.2 \mathrm{~m}^{2} /$ ha we obtain $F=0.38$ which is close to the generic model. 
Appendix A3. Wood density.

Lisa A3. Puidu tihedus.

The wood density $(\delta)$ values (Table A3.1) 0.9 to account for bark, since stem diawere used for Chave et al. (2015) model apmeters were measured over bark. For plied to trees growing on Estonian Network grey alder $10 \%$ of branches were conof Forest Research sample plots (Kiviste et al., 2014) to estimate their above-ground biomass. The values were multiplied by sidered (Uri et al., 2014). The constant of $0.45 \mathrm{~g} / \mathrm{cm}^{3}$ was used for all other tree species not listed in Table (A3.1).

Table A3.1. Wood density $(\delta)$.

Tabel A3.1 Puidu tihedus ( $\delta$ ).

\begin{tabular}{lcl}
\hline $\begin{array}{l}\text { Tree species } \\
\text { Puuliik }\end{array}$ & $\begin{array}{l}\delta \\
\mathrm{g} / \mathrm{cm}^{3}\end{array}$ & $\begin{array}{l}\text { Source } \\
\text { Allikas }\end{array}$ \\
\hline Pinus sylvestris & 0.453 & Kask (2003) \\
Picea abies & 0.420 & Saarmann \& Veibri (2006) \\
Betula pendula & 0.650 & Uri et al. (2012) \\
Populus tremula & 0.470 & Saarmann \& Veibri (2006) \\
Alnus glutinosa & 0.490 & Saarmann \& Veibri (2006) \\
Alnus incana & 0.403 & Uri et al. (2014) \\
Tilia cordata & 0.470 & Saarmann \& Veibri (2006) \\
Fraxinus excelsior & 0.640 & Saarmann \& Veibri (2006) \\
Quercus robur & 0.650 & Saarmann \& Veibri (2006) \\
\hline
\end{tabular}


Appendix 4. Biomass predictor variables of FGN stands.

Lisa 4. Biomassi seosed takseertunnustega metsa kasvukäigu uuringute proovitükkidel.

Above-ground biomass for forest growth network plots (Kiviste et al., 2014) was obtained by estimating first biomass for each tree with Repola $(2008,2009)$ or Marklund (1988) model and then aggregating tree biomass for each sample plot. Single tree biomass is usually estimated based on the tree stem diameter. However, stand mean diameter is less informative predictor for biomass in Estonia compared to forest height or stand basal area (Figure A4.1). Mõistus and Lang (2015) found that stand mean height was good predictor for foliage mass in deciduous stands in Järvselja, Estonia.
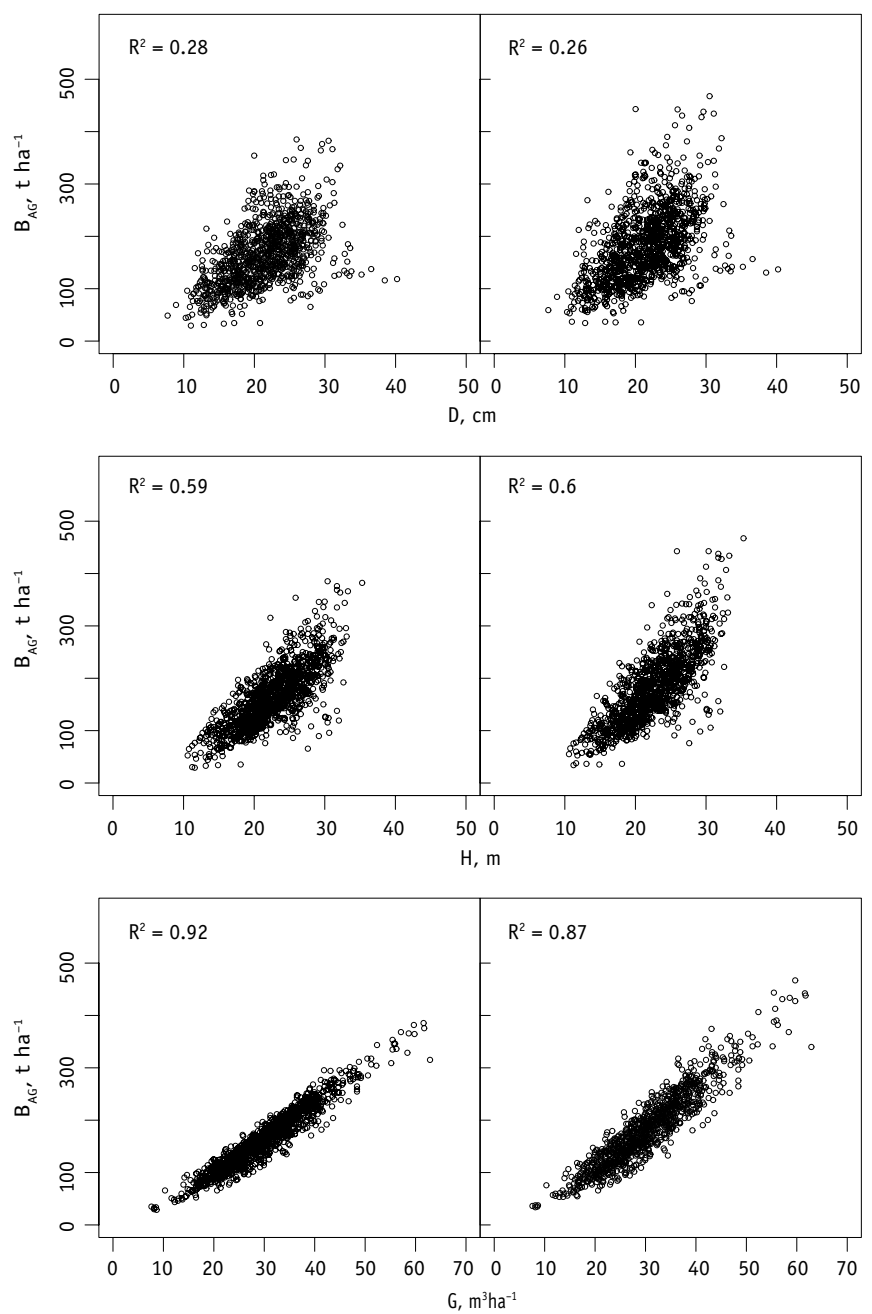

Figure A4.1. Above-ground biomass of forest growth study network (Kiviste et al., 2014) plots as a function of stand mean breast height diameter, stand height and basal area. Left: Repola $(2008,2009)$, right: Marklund (1988).

Joonis A4.1. Puistu maapealse osa biomassi ja puistu takseertunnuste seosed metsa kasvukäigu proovitükkidel. Biomassi hindamiseks kasutati Repola $(2008,2009)$ (vasakul) ja Marklundi (1988) mudeleid (paremal). 
Appendix 5. Species specific parameters for model (2).

Lisa $5 . \quad$ Puuliigiti lähendatud mudeli (2) parameetrite hinnangud.

We constructed new stand level above- tion term of the grey alder model had a ground biomass models (Table A5.1) for relatively large standard error and $p=0.1$. grey alder and silver birch. Data for grey However, to avoid biomass overestimation alder stands are from Võsu (2012) and Uri in young stands the start correction was et al. (2014). Data for silver birch stands are included into the model. The model input from Uri et al. (2012) (except forest "Kooraste2"), Varik et al. (2009) and Zasada et al. (2014). The parameter for start correcvalues for $G$ and $H$ are regular measures obtained in forest inventory practice.

Table A5.1. Parameters for biomass model (2) in grey alder and silver birch stands. Standard error is in parentheses.

Tabel A5.1. Mudeli (2) parameetrite hinnangud hall-lepikutele ja arukaasikutele. Sulgudes on hinnangute standardvead.

\begin{tabular}{lcc}
\hline Model component & \multicolumn{2}{c}{ Model component values / Hinnangud } \\
\cline { 2 - 3 } Mudeli osa & Alnus incana & Betula pendula \\
\hline$R_{\text {adj }}^{2}$ & 0.9465 & 0.9868 \\
Deg. of freedom & 31 & 22 \\
RSE (t/ha) & 10.2 & 6.9 \\
a1 & $19.73(5.3)$ & $22.37(4.3)$ \\
a2 & $0.1842(0.011)$ & $0.2457(0.010)$ \\
a3 & $-17.1(10.2)$ & $-17.3(5.7)$ \\
\hline
\end{tabular}




\title{
Puistute maapealse osa biomassi hindamine rinnaspindala ja kõrguse järgi
}

\author{
Mait Lang, Ando Lilleleht, Mathias Neumann, Karol Bronisz, Samir G. Rolim, \\ Meelis Seedre, Veiko Uri ja Andres Kiviste
}

Kokkuvõte

Puistute biomassi salvestunud süsinik võimaldab mõneti leevendata fossiilsete kütuste kasutamisest tingitud kliima soojenemist (Nabuurs et al., 2007), aga samasuguse puu kohta saadud biomassi hinnangud võivad riigiti oluliselt erineda (Neumann et al., 2016). Tüüpiliselt kasutatakse üksikpuude mudeleid (Ter-Mikaelian \& Korzukhin, 1997; Zianis et al., 2005; Henry et al., 2013; Marklund, 1988; Repola, 2008, 2009; Chave et al., 2005, 2015), mis põhinevad puu rinnasdiameetril $d$. Selliste mudelite põhjal jõudsid Stephenson et al. (2014) järeldusele, et suuremad puud salvestavad rohkem süsinikku. Puistut tervikuna vaadates tuleb aga arvestada puudevahelise konkurentsiga ja suremusega (Enquist \& Niklas, 2002; Nilson, 2005). Cannell (1984) näitas, et puistute maapealse osa biomassi $B_{A G}(\mathrm{t} / \mathrm{ha})$ hindamiseks sobib lihtne mudel, kus argumendiks on puistu kõrgus $H(\mathrm{~m})$ ja rinnaspindala $(G)\left(\mathrm{m}^{2} / \mathrm{ha}\right)$. Käesolevas töös koostati kirjanduse (tabel A1.1) põhjal mudelid (1, 2, tabel 1, joonis 1), mida kasutati Marklund (1988) ja Repola $(2008,2009)$ üksikpuude biomassi mudelite hinnangute ja puudevahelise konkurentsi seoste uurimiseks metsa kasvukäigu uuringute proovitükkide (Kiviste et al., 2014) mõõtmisandmetel (tabel A1.2). Analüüsiti ka Neumann et al. (2016) töös kasutatud standardpuistutele erinevate maade mudelitega saadud biomassi hinnanguid, publitseeritud biomassi andmeid Korea tammikutest, Amazonase vihmametsast ja Tšiilist ning biomassi mõõtmisandmeid Brasiiliast, Eestist ja Poolast. Metsa kasvukäigu uuringute proovitükkidel arvutati biomassi hinnangud ka mudeliga (4) Chave et al. (2015) tööst kasutades tabelis A3.1 toodud puidu tihedusi. Puudevahelise konkurentsi hindamiseks arvutati 1) $N_{t}$ puu alusel, mis asusid $8 \mathrm{~m}$ proovitüki piirist seespool, $C I_{\text {Hegyi }}(3)$, kus $s_{i j}$ on puu $j$ kaugus kuni $8 \mathrm{~m}$ olevast naabrist $i$ ja 2) $C I_{L T T}$ (4) tuginedes puistu hõredusele $L$ (Nilson, 2005) ja piirtihedusele $L_{T J}$ (Sims et al., 2009).

Selgus, et puistu keskmine kõrgus on Eestis seotud maapealse osa biomassiga paremini kui keskmine tüveläbimõõt $D$ (joonis A4.1). Marklundi (1988) mudelitega saadi süstemaatiliselt suuremad biomassi hinnangud $B_{A G(M)}$ kui uuemate Repola $(2008,2009)$ mudelitega $\left(B_{A G(R)}\right)$ (joonis 2). Konkurentsiindeksid kirjeldasid eraldivõetuna küll üsna suure osa biomassi variatsioonist (joonis 3, tabel 3), kuid lisaks puistu rinnaspindalale ja kõrgusele nad mudelit oluliselt ei paranda. Puistu hõredusel põhineva konkurentsiindeksi $C_{L T J}$ järgi ilmnes aga selgelt, et võrreldes üldise keskmisega on rohkem biomassi puistutes, kus puudevaheline konkurents on suurem.

Üldist mudelit (2) kasutades selgus $\mathrm{ka}$, et erinevate Euroopa maade biomassi hindamise meetodite erinevus ilmneb selgelt ka puistute tasemel (joonis 4). Mudeli (2) abil ei saanud hästi kirjeldada Korea tammikute biomassi (joonis 5), mille vormiarvu ja puidu tiheduse kohta polnud kahjuks konkreetseid andmeid. Samas kirjeldas mudel hästi Brasiilias, Eestis ja Poolas mõõdetud puistute biomassi (joonis 5). Eesti ja Poola andmetel lähendati mudelile (2) eraldi parameetrid hall-lepikute ja arukaasikute jaoks (tabel A5.1).

Kokkuvõtteks: 1) teistsugustest kasvutingimustest pärinevate puude mõõtmisandmetel koostatud biomassimudelid (vanad mudelid) võivad anda süstemaatilise 
veaga hinnanguid, 2) puistutes, mille eesmärgiks on süsiniku salvestamine, peab puudevaheline konkurents olema suur ning harvendusraieid tuleks kasutada ainult suurema puidutihedusega või suurema bioloogilise vanusega puuliikidele eelise andmiseks, ja 3) puude biomassi mõõtmisandmed Eestist ja Euroopast tuleb koondada mudelite arendamiseks ja metoodikate sarnastele alustele viimiseks ühtsesse andmebaasi nagu on tehtud troopikapuude andmetega.

Received July 14, 2016, revised October 12, 2016, accepted October 13, 2016 